\title{
Students' Project Competency within the Framework of STEM Education
}

\author{
https://doi.org/10.3991/ijet.v15i21.15933 \\ Elena A. Levanova $(\bowtie)$ \\ Moscow Pedagogical State University, Moscow, Russia \\ elena.a.levanova@gmail.com \\ Olga V. Galustyan \\ Southern Federal University, Rostov-on-Don, Russia \\ Svetlana B. Seryakova, Tatyana V. Pushkareva \\ Moscow Pedagogical State University, Moscow, Russia \\ Anna B. Serykh \\ Immanuel Kant Baltic Federal University, Kaliningrad, Russia \\ Alexey V. Yezhov \\ Southern Federal University, Rostov-on-Don, Russia
}

\begin{abstract}
The paper devoted to the problem of students' project competency within the framework of STEM education. Project competency is an important component of professional competency of a future specialist and is applicable to designate professionalism. The article refers to the major features of STEM education which serve as means of development of project competency of students. Project competency means possession of special knowledge, skills and abilities (to solve problems on the basis of putting forward and substantiating hypotheses, to set an activity goals, to plan activities, to collect and to analyze necessary information, to carry out an experiment, to present research results). Authors conclude that STEM education provides the development of students' project competency.
\end{abstract}

Keywords-Project competency, activity, students, STEM education

\section{Introduction}

Education is a combination of development, upbringing, and training of students which undergoes changes inevitably, adapting to the current situation in the world, helping students to form necessary skills for their future profession. Development of science leads to emergence of new areas of knowledge, there is an increasing need for proactive, knowledgeable specialists [8].

STEM education deals with presentation of sciences, technologies, engineering, and mathematics in such a combination which is necessary for full understanding of a 
subject and an effective future work. It provides students with the opportunity to model their learning plan based on their interests, experience, and skills independently $[1,9,16]$. Project competency is an integrative personality characteristic which is expressed in readiness for independent theoretical and practical activities in creating projects. STEM education lays the foundation for an independent person who understands his / her own abilities and has initiative for project activities [6, 11, 24].

\section{Methodology}

It is necessary to identify its essence, scope, and main characteristics of STEMeducation for the further analysis and understanding of the opportunities provided by it.

STEM stands for Science, Technology, Engineering, and Mathematics. Natural sciences which include study of world and laws of physics, chemistry, and biology, as well as the handling of facts, principles, and concepts inherent in these fields of knowledge. Natural sciences form the basis of knowledge, which is formed in human development and helps to generate new knowledge. Project process is carried out based on natural sciences [5, 10,21].

Process of project activity of students within the framework of STEM education teaches them:

1. To ask questions regarding the nature of the certain phenomena

2. To create and to use models in order to demonstrate natural processes

3. To plan and to conduct research

4. To analyze and to interpret data using the skills of mathematical thinking

5. To make explanations of processes and theories

6. To enter into disputes, citing evidences

7. To accumulate, to transform and to transmit information

These tasks are performed within the framework of accepted concepts and categories by natural science which are presented to students during the learning process (for example, such categories as regularity, cause, effect, quantity, ratio, energy, matter, structure, functions, stability, change, etc.).

STEM education is understood as teaching how to understand technology, how to use it, and how to use it further in cognition. It implies that students have access for receiving and processing data to various technical devices such as sensors, computers, and so on. Students develop computational thinking, including steps of formulating a problem, presenting solution, executing, and evaluating solution. Due to the diversity of approaches, algorithmic techniques, logic and orderliness such thinking is considered as fundamental skill for process of project activity of students within the framework of STEM education $[2,7,25]$.

Scientists $[3,13,22]$ highlight that STEM education includes the basis of knowledge embedded in objects created by man, and project process itself which is limited by certain conditions, such as laws of nature, development of technology, time, materials, environmental friendliness which are necessary for implementation of 
a project. STEM education uses scientific and mathematical concepts as well as and mobile devices $[12,18]$. Especially important is to use game technologies within the framework of STEM education [17, 19, 20].

Project activity within the framework of STEM education allows:

1. To focus on the practical issues and problems (during the lesson students apply scientific knowledge in practice, solving social, ecological, and environmental issues)

2. To use the methods of engineering project process (students conduct their preliminary study, rely on several options for resolving the situation, use methods of statistics, analysis and optimization, taking into account not only the scientific basis, but also social need which is essential for their work for practical functioning)

3. To focus on involvement of students in practical studies (theoretical knowledge is tested and demonstrated in several ways; students develop their project skills in reproducing and using the laws of nature in laboratories);

4. To focus on productive teamwork (students are given opportunity to regulate their work in group independently, to distribute responsibilities, to set up goals, to analyze results, to work with each other)

5. To use qualitative scientific sources

Project activity within the framework of STEM education is integrated into the content of practical tasks, the subject matter of which is determined by the training program. Subject knowledge is given in the form of informational inclusion which holds brief explanatory texts and links to selected information resources of Internet which act as means of solving educational problem. Students will not be able to complete tasks without meeting a new concept or formula. Therefore, information is always given to students only after formulation of educational tasks for the solution of which it is needed. This format of educational work determines the amount of mastered content. It means that information becomes less, but the quality of its "appropriation" by the students' changes [4, 15, 23].

\section{$3 \quad$ Materials and Methods}

\subsection{Participants}

We conducted experimental work on the development of project competency in 2018-2019. Students of two universities (Moscow Pedagogical State University, Moscow; Southern Federal University, Rostov-on-Don) participated in the study. The total number of students was 207 (103 participants were in experimental group, control group included 104 participants). Age range of the students was from 18 to 19 years. 


\subsection{Activity}

Students of experimental and control groups carried out research projects which were aimed at the formation of scientific type of thinking. Students of control group carried out projects within traditional method.

Formation of students' project competency of the experimental group was realized within the framework of STEM education. Students' individual and group work was organized. Students were provided with the infrastructure which was necessary for realization of projects (equipment, computers, literature recourses, etc.). Project work schedule was formed. Teachers served functions of project engineers and tutors.

Project activity within the framework of STEM education was aimed at:

1. Activation of cognitive activity of students

2. Creating conditions for rapid development of talented students

Project activity within the framework of STEM education contained study of the discipline "Creative project", which was implemented in the first course (at first and second terms). During this course students carried out two creative team projects and one individual project. Teachers delivered topics of projects and brief description of the project assignment.

Students worked in mini groups of 3-5 people with a high degree of independence. They completed tasks which were placed in electronic information environment. Teachers played role of assistants, facilitators of group work. They monitored current work of the students provided assistance and feedback. Teachers evaluated work the of students in the electronic information environment in accordance with the system of criteria.

Educational environment was focused on the practical activities of the students. It was transformed to solve various problems easily. Educational equipment was intended for the use by students for practical (laboratory) work.

\subsection{Stages of realization of the project}

Stages of realization of the project included:

1. Choosing of topics for creative projects and determining the terms of their realization

2. Formation of project team

3. Choosing a team leader and distributing roles in the team

4. Attending consultations which were related to the upcoming implementation of the project

5. Attending additional lectures and seminars on the topics which were necessary for successful implementation of the project

6. Monitoring of the performance of the project

7. Providing a report on the work which was done 


\subsection{Methods of assessment}

Three methods of assessment were used. They were operational feedback, highquality ongoing assessment of each completed practical work, and criteria-based assessment, which was based on the results of the final work of students. The main form of assessment was formative assessment. It means that students received assignments not for the purpose of checking of their knowledge and skills, but for the purpose of checking of for their formation. Accordingly, errors were normal, and their appearance was not met by a negative assessment, but by a positive feedback which meant clarification of what needed correction and how to do it. Feedback was given directly during the implementation of practical work to the group of students and individually. Assessment of the results of each student's work took place every lesson. The results of work that students placed in the electronic informational environment were evaluated. The main form was report on laboratory work, in which answers to questions, results of assignments, experiments were recorded. It allowed to evaluate knowledge and subject skills [14].

\section{$4 \quad$ Results}

Project competency is expressed in the possession of special knowledge, skills and abilities (to solve problems on the basis of putting forward and substantiating hypotheses, to set an activity goal, to plan activities, to collect and to analyze necessary information, to carry out an experiment, to present research results). Project competency is an indicator of personal development as a result of mastery of project activities. Project competency includes information, research, and analytical components. Information component involves ability to obtain information concerning existing knowledge, and its generalization; to compilate of a stating nature of the research topic; ability to work with educational literature, ability to use directories and tables. Research component is expresses in preparation of an experiment plan, forecasting its results, finding causal relationships, ability to conduct observations, experiments, and formulating conclusions. Analytical component involves analysis and critical assessment of existing knowledge, formulation of the research problem based on identification of partially or completely unstudied aspects of the research topic.

The practical implementation of the research process of evaluating of project competency was carried out in the form of an analysis based on Likert scale. The results of the study are presented in Table 1 and Table 2. 
Table 1. Level of project competency in the experimental and control groups at the beginning of the experiment

\begin{tabular}{|l|c|c|c|c|c|c|}
\hline \multirow{2}{*}{ Project competency } & \multicolumn{3}{|c|}{ Experimental group } & \multicolumn{3}{c|}{ Control group } \\
\cline { 2 - 7 } & Low level, \% & $\begin{array}{c}\text { Middle level, } \\
\text { \% }\end{array}$ & $\begin{array}{c}\text { High level, } \\
\text { \% }\end{array}$ & Low level, \% & $\begin{array}{c}\text { Middle level, } \\
\text { \% }\end{array}$ & $\begin{array}{c}\text { High level, } \\
\text { \% }\end{array}$ \\
\hline $\begin{array}{l}\text { Information } \\
\text { component }\end{array}$ & 40.5 & 38.4 & 21.1 & 39.7 & 39.4 & 20.9 \\
\hline Research component & 56.0 & 28.2 & 15.8 & 37.2 & 38.9 & 23.9 \\
\hline Analytical component & 56.6 & 29.8 & 13.6 & 44.1 & 34.8 & 21.1 \\
\hline
\end{tabular}

Table 2. Level of project competency in the experimental and control groups at the end of the experiment

\begin{tabular}{|l|c|c|c|c|c|c|}
\hline \multirow{2}{*}{ Project competency } & \multicolumn{3}{|c|}{ Experimental group } & \multicolumn{3}{c|}{ Control group } \\
\cline { 2 - 7 } & Low level, \% & $\begin{array}{c}\text { Middle level, } \\
\%\end{array}$ & $\begin{array}{c}\text { High level, } \\
\%\end{array}$ & Low level, \% & $\begin{array}{c}\text { Middle level, } \\
\%\end{array}$ & $\begin{array}{c}\text { High level, } \\
\%\end{array}$ \\
\hline $\begin{array}{l}\text { Information } \\
\text { component }\end{array}$ & 12.9 & 37.5 & 49.6 & 41.2 & 38.4 & 20.4 \\
\hline Research component & 8.1 & 26.8 & 65.1 & 34.6 & 42.9 & 22.5 \\
\hline Analytical component & 5.6 & 27.4 & 67.0 & 42.7 & 36.7 & 20.6 \\
\hline
\end{tabular}

Measuring of the level of project competency in the experimental group at the beginning and at the end of the experiment revealed that the number of students who have reached high level in the experimental group has increased significantly at the end of the experiment. The number of students who have reached high level in the control group hasn't almost changed at the end of the experiment. It proves the effectiveness of the experimental work.

\section{Conclusion}

Students' project activity within the framework of STEM education is focused on solving of practical problems. Students' activities include complex interactions between team members and are dependent on communication, planning, and ability to work effectively in team. Project activity is a student-centered learning, in which the role of the teacher shifts from the exclusive possession and dissemination of knowledge to personal support and assistance in choosing tools and methods. We consider that following the recommendations for implementation of students' project activity within the framework of STEM education will increase the effectiveness of students' project activity work. They include the following items:

1. Teachers should focus on the practical issues and problems while formulating topics of the projects.

2. Students should be supplied with various technical devices such as sensors, computers, electronic information environment, literature recourses and so on.

3. Subject knowledge should be given in the form of informational inclusion which contains brief explanatory texts and links to selected information resources of Internet. 
4. Teachers should focus the students on their teamwork to provide the effectiveness of students' project work.

5. Teachers should provide necessary assistance to the students serving as tutors and facilitators.

During the training students gain experience in project work in their future profession, they understand the relationship of theory and practice and importance of teamwork, and they also develop ability to complete the work to the end in time.

\section{Acknowledgement}

This publication was supported by Southern Federal University.

\section{$7 \quad$ References}

[1] Beswick, K., \& Fraser, S. (2019). Developing mathematics teachers' 21st century competence for teaching in STEM contexts. ZDM - Mathematics Education, 51(6), 955965. https://doi.org/10.1007/s11858-019-01084-2

[2] Birney, L., \& Cronin, J. (2019). Environmental habitat restoration and inquiry-based learning with new york city public schools - an urban model in STEM education. Journal of Environmental Studies and Sciences, 9(3), 322-326. https://doi.org/10.1007/s13412-01 $\underline{8-0530-5}$

[3] Butcher, J., Clarke, A., Wood, C., McPherson, E., \& Fowle, W. (2019). How does a STEM access module prepare adult learners to succeed in undergraduate science? Journal of further and Higher Education, 43(9), 1271-1283. https://doi.org/10.1080/0309877x.2018.1 $\underline{476679}$

[4] Carbonell-Carrera, C., Saorin, J. L., Melian-Diaz, D., \& de la Torre-Cantero, J. (2019). Enhancing creative thinking in STEM with 3D CAD modelling. Sustainability (Switzerland), 11(21) https://doi.org/10.3390/su11216036

[5] Cetron, J. S., Connolly, A. C., Diamond, S. G., May, V. V., Haxby, J. V., \& Kraemer, D. J. M. (2019). Decoding individual differences in STEM learning from functional MRI data. Nature Communications, 10(1) https://doi.org/10.1038/s41467-019-10053-y

[6] Delaney, J. M., \& Devereux, P. J. (2019). Understanding gender differences in STEM: Evidence from college applications 2 . Economics of Education Review, 72, 219-238. https ://doi.org/10.1016/j.econedurev.2019.06.002

[7] Galustyan, O. V., Borovikova, Y. V., Polivaeva, N. P., Kodirov, B. R., \& Zhirkova, G. P. (2019). E-learning within the field of andragogy. International Journal of Emerging Technologies in Learning, 14(9), 148-156. https://doi.org/10.3991/ijet.v14i09.10020

[8] Galustyan, O. V., Gaidar, K. M., Aleshina, S. A., Ksenofontova, A. N., \& Ledeneva, A. V. (2018). Development of group subjectivity of pupils within collaborative activities. TEM Journal, 7(4), 854-858. doi:10.18421/TEM74-25

[9] Galustyan, O. V., Meshcheryakova, E. I., Larina, T. V., Bakleneva, S. A., \& Krivotulova, E. V. (2018). Self-regulated learning of students at university. Espacios, 39(23)

[10] Gehrke, S., \& Kezar, A. (2019). Perceived outcomes associated with engagement in and design of faculty communities of practice focused on STEM reform. Research in Higher Education, 60(6), 844-869. https://doi.org/10.1007/s11162-018-9534-y 
[11] Hallström, J., \& Schönborn, K. J. (2019). Models and modelling for authentic STEM education: Reinforcing the argument. International Journal of STEM Education, 6(1) https ://doi.org/10.1186/s40594-019-0178-Z

[12] Kalogiannakis, M., \& Papadakis, S. (2017). Combining mobile technologies in environmental education: a Greek case study. International Journal of Mobile Learning and Organisation, 11(2), 108-130. https://doi.org/10.1504/ijmlo.2017.10005249

[13] Korte, A. (2019). Interactive early education builds STEM literacy in children. Science, 365(6456), 876-877. https://doi.org/10.1126/science.365.6456.876

[14] Leung, A. (2019). Exploring STEM pedagogy in the mathematics classroom: A tool-based experiment lesson on estimation. International Journal of Science and Mathematics Education, 17(7), 1339-1358. https://doi.org/10.1007/s10763-018-9924-9

[15] Maulana, I. T., Hary, R. D., Purwasih, R., Firdian, F., Sundara, T. A., \& Na'am, J. (2019). Project-based learning model practicality on local network devices installation subject. International Journal of Emerging Technologies in Learning, 14(15), 94-106. https://doi. org/10.3991/ijet.v14i15.10305

[16] Olmstead, A., Beach, A., \& Henderson, C. (2019). Supporting improvements to undergraduate STEM instruction: An emerging model for understanding instructional change teams. International Journal of STEM Education, 6(1) https://doi.org/10.1186/s405 94-019-0173-4

[17] Papadakis, S. (2020). Evaluating a game-development approach to teach introductory programming concepts in secondary education. International Journal of Technology Enhanced Learning, 12(2), 127-145. https://doi.org/10.1504/ijtel.2020.106282

[18] Papadakis, S., \& Kalogiannakis, M. (2017). Using gamification for supporting an introductory programming course. the case of classcraft in a secondary education classroom. In Interactivity, Game Creation, Design, Learning, and Innovation, 366-375. https://doi.org/10.1007/978-3-319-76908-0 35

[19] Papadakis, S., \& Orfanakis, V. (2016). The combined use of Lego Mindstorms NXT and App Inventor for teaching novice programmers. International Conference EduRobotics, 193-204. https://doi.org/10.1007/978-3-319-55553-9_15

[20] Petelin, A. S., Galustyan, O. V., Prosvetova, T. S., Petelina, E. A., \& Ryzhenkov, A. Y. (2019). Application of educational games for formation and development of ICT competence of teachers. International Journal of Emerging Technologies in Learning, 14(15), 193-201. https://doi.org/10.3991/ijet.v14i15.10572

[21] Reinholz, D. L., \& Andrews, T. C. (2019). Breaking down silos working meeting: An approach to fostering cross-disciplinary STEM-DBER collaborations through working meetings. CBE Life Sciences Education, 18(3) https://doi.org/10.1187/cbe.19-03-0064

[22] Rowland, A. A., Dounas-Frazer, D. R., Ríos, L., Lewandowski, H. J., \& Corwin, L. A. (2019). Using the life grid interview technique in STEM education research. International Journal of STEM Education, 6(1) https://doi.org/10.1186/s40594-019-0186-Z

[23] Schlegel, R. J., Chu, S. L., Chen, K., Deuermeyer, E., Christy, A. G., \& Quek, F. (2019). Making in the classroom: Longitudinal evidence of increases in self-efficacy and STEM possible selves over time. Computers and Education, 142 https://doi.org/10.1016/j.comp edu.2019.103637

[24] Weissmann, G. S., Ibarra, R. A., Howland-Davis, M., \& Lammey, M. V. (2019). The multicontext path to redefining how we access and think about diversity, equity, and inclusion in STEM. Journal of Geoscience Education, 67(4), 320-329. https://doi.org/10.10 $\underline{80 / 10899995.2019 .1620527}$ 
[25] Zhang, H. (2019). A flipped classroom-based education system for college English teaching. International Journal of Emerging Technologies in Learning, 14(16), 120-129. https://doi.org/10.3991/ijet.v14i16.11152

\section{Authors}

Elena A. Levanova is Professor, Head of Department of Social Pedagogy and Psychology, Faculty of Pedagogy and Psychology, Moscow Pedagogical State University, Moscow, Russia.

Olga V. Galustyan is Professor of the Department of Education and Pedagogical Sciences of Southern Federal University, Rostov-on-Don, Russia.

Svetlana B. Seryakova is Professor of Department of Social Pedagogy and Psychology, Faculty of Pedagogy and Psychology, Moscow Pedagogical State University, Moscow, Russia.

Tatyana V. Pushkareva is Professor of Department of Social Pedagogy and Psychology, Faculty of Pedagogy and Psychology, Moscow Pedagogical State University, Moscow, Russia.

Anna B. Serykh is Professor of Institute of Education of Immanuel Kant Baltic Federal University, Kaliningrad, Russia.

Alexey V. Yezhov is Postgraduate of the Department of Education and Pedagogical Sciences of Southern Federal University, Rostov-on-Don, Russia.

Article submitted 2020-06-01. Resubmitted 2020-07-21. Final acceptance 2020-07-21. Final version published as submitted by the authors. 